\title{
CSR Communication: The Use of Internet-Based Tools*
}

\author{
Alessia D'Andrea**, Lucia Pizzichini***, \\ Stefano Marasca ${ }^{* * * *}$, Gian Luca Gregori ${ }^{* * * *}$
}

\begin{abstract}
Corporate communication plays an important role in establishing and maintaining transparent and open dialogues with different stakeholders to foster ethical and socially responsible actions. The advent of the internet not only reorganized the way in which companies collect information, but also redefined stakeholders' expectations. This paper investigates the potential of internet-based communication tools to disclose CSR topics. The study analyses the extent to which the Dow Jones Sustainability Index companies are using the internet-based tools to foster one-way and two-way communications and, so, to develop a dialogue with stakeholders. The research suggests a prevalence of one-way communication through internet-based tools but, at the same time, a large dissemination of social network channels.
\end{abstract}

Keywords: CSR Communication; Digital Tools; Social Network Channels; Stakeholder Engagement; DJSI Listed Companies; Global Markets.

\section{CSR Communication and Internet-Based Tools}

In the last decade, many international organisms underlined the importance - for business - to communicate CSR initiatives and social responsibility behaviors. In this scenario, the OECD Guidelines as well as the standard ISO 26000 explain the role of communication in social responsibility, its characteristics and the different types of communication that can be used. These two international references for organizations pointed out that the "reporting to stakeholders can be done in many different ways, including meetings with stakeholders, letters describing the organization's activities related to social responsibility for a defined period, Website information and periodic social responsibility reports" (ISO-OECD, 2017). It is strongly recognized that "information and communication technologies characterize much of contemporary life and are a valuable basis for many economic activities" (ISO-OECD, 2017). The United Nation underlined the

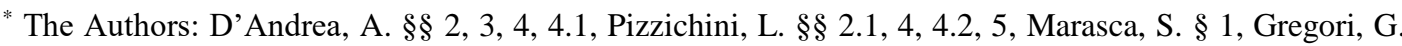
L. $\S 5$.

** Assistant Professor of Accounting, Polytechnic University of Marche (a.dandrea@staff.univpm.it)

**** Research Fellow in Marketing, Polytechnic University of Marche (1.pizzichini@ @taff.univpm.it)

**** Full Professor of Accounting, Polytechnic University of Marche (s.marasca@staff.univpm.it)

****** Full Professor of Marketing, Polytechnic University of Marche (g.gregori@ @taff.univpm.it)
}

Edited by: Niccolò Cusano University

ISSN: $1593-0319$

D’Andrea, A., Pizzichini, L., Marasca, S., \& Gregori, G. L. (2019). CSR Communication: The Use of Internet-Based Tools. Symphonya. Emerging Issues in Management (symphonya.unicusano.it), 2, 38-59.

http://dx.doi.org/10.4468/2019.2.05dandrea.pizzichini.marasca.gregori 
relevance of communication by business enterprises on how they address their impacts on human rights and recognized that the "communication can take a variety of forms, including in-person meetings, online dialogues, consultation with affected stakeholders, and formal public reports" (including corporate responsibility/sustainability reports) (United Nation, 2011). There are several communication tools/channels through which information can be disseminated. A company can communicate its CSR activities through official documents, such as an annual corporate responsibility report or press releases and dedicate a section of its official corporate website to CSR; it can also use TV commercials, magazine or billboard advertisements, and product packaging to communicate its CSR initiatives (Morsing \& Schultz, 2006).

In corporate communication, Internet provides organizations with "a cheap, fast and easy information dissemination tool" (Jose \& Lee, 2007: 308), as well as advanced potential for interactivity (Unerman, \& Bennett, 2004). Organizations' websites and Internet-based tools play a potentially significant role in enhancing company interaction with stakeholder; the use of Internet communications by organisations, particularly social media, is growing rapidly (Bochenek \& Blili, 2013; Li \& Li, 2014; Lodhia \& Stone, 2017; Bosetti, 2018; Nelson, 2019). Many scholars provided evidence of a diffuse use of the website for CSR disclosure by companies (Adams \& Frost, 2006; Bartkus et al., 2002; Esrock \& Leichty, 1998; Maier \& Ravazzani, 2019; Moreno \& Capriotti, 2009; Siano et al., 2016; Tagesson et al, 2009; Tetrevova et al., 2019; Wanderley et al., 2008; Williams \& Wern Pei, 1999). Several researches focused on the on-line reports published by companies (Correa-Garcia et al., 2018; Guillamón-Saorín \& Martínez-López, 2013; Hahn \& Kühnen, 2013; Jose \& Lee, 2007; Junior et al. 2014; Lodhia, 2014; Lodhia \& Stone, 2017). A part of the literature underlined the internet potential to establish a two-way communication and foster a dialogue with stakeholders on CSR topics (Esrock, \& Leichty, 1998; Unerman, \& Bennett, 2004). Recent studies focused on the use of social media in CSR communication (Manetti \& Bellucci, 2016; Chae \& Park, 2018). This new medium is considered an excellent broad-based tool to disseminate information and to foster two-way communication; to define and control their image, and a good environment to show CSR as well as to communicate with different stakeholders (Adi \& Grigore, 2005; Bondy et al., 2004; Du et al., 2010; Li \& Li, 2014; Bosetti, 2018; Nelson, 2019; Re \& Giachino, 2018; Taylor \& Kent, 2014).

In line with the growing demand for accountability and transparency, the last Corporate Sustainability Assessment of SAM (for DJS index rating) increased the number of requests of publicly available information, in order to respond to "investor demand for greater transparency and more readily available information in the public domain" (SAM, 2019). SAM stressed that "Publicly available information should be directly accessible through navigation from your company's own website or a related website" (SAM, 2019).

In this field, the paper aims to empirically investigate the use of Internet-based tools by the listed companies of the DJS index to foster communication on social, environmental, and ethical issues. The research questions are "How (and if) are DJSI companies using the Internet-based tools as CSR communication tool?" This examination was constructed using data from content analysis to the corporate web 
sites of the companies listed on the DJS index. In this respect, the use of Internetbased tools is investigated by exploring their typology (principally: presence of CSR section and CSR reporting, e-mail/forms as direct contact, FAQs, forums/blogs, social media channels, reports on stakeholder meetings, accessibility issues) and the ease of access of each tool (checking the proximity to the home page).

The paper is structured as follow: at first the study outlines the CSR communication background and review the relevant literature on digital tools. Later, a demonstration of digital tools adopted by DJS index listed companies is given. Finally, the results are discussed and implication for managers suggested, underlining the limitation of the study.

\section{One-Way and Two-Way CSR Communication}

Corporate communication plays an important role in establishing and maintaining transparent and open dialogues with different stakeholders to foster ethical and socially responsible actions (Bartkus Glassman, \& McAfee, 2002; Frostenson et al., 2011; Jose \& Lee, 2007; Kim, 2014; Kim \& Ferguson, 2018; Morsing \& Schultz, 2006; Moreno \& Capriotti, 2009; Patten, 2002; Seele \& Lock, 2015; Williams \& Ho Wern Pei, 1999).

$\square$ Several communication strategies, including proactive and
ongoing dialogue (Morsing \& Schultz, 2006), can allow
stakeholders to be able to participate, to have a voice, to share
organization activities and to be well-informed (Backstrand \&
Saward, 2004). The international forum of CSR communication
defines this concept as: "a process of anticipating stakeholder
expectations, articulation of corporate socially responsible policy
and the managing of different communication tools designed to
provide true and transparent information about a company or a
brand's integration of its business operations, social and
environmental concerns, and interactions with stakeholders".

In order to establish dialogues with their stakeholders, companies employ a variety of communication tools (Mosca \& Civera, 2017), such as internet bulletin boards, questionnaire surveys mailed to stakeholders, phone surveys, and community based and/or open meetings presentations at conferences, stakeholder panels facilitated by outside organizations, briefings with key opinion leaders and members of the government, focus groups, open forums/workshops, in-house newspapers, interviews, web/phone hotlines, briefing sessions, internet 'web forums', advertisements, corporate brochures, press releases and company web-site pages, social channels, CD ROMS and videos (Adams \& Frost, 2006; Li and Li, 2014; Owen et al., 2001; Swift, 2001; Thomson \& Bebbington, 2005; Unerman \& Bennett, 2004).

In the literature, these tools are categorized in two typologies of CSR communication: those which allow one-way communication and those which foster 
two-way communication (Kim, 2014; Morsing \& Schultz, 2006; Seele \& Lock, 2015). Morsing and Schultz (2006) recognized that it is possible to find three types of stakeholder relations in terms of how companies strategically engage them in CSR communication: the stakeholder information strategy; the stakeholder response strategy; and the stakeholder involvement strategy. The first involves a one-way communication; the stakeholder response strategy is based on a 'two-way asymmetric' communication model, where the company has the sole intention of convincing its stakeholders of its attractiveness.

In contrast, the stakeholder involvement strategy assumes a dialogue with its stakeholders, who can potential influence the company's expectations and change the company itself. Seele and Lock (2015) classified CSR communication tools, taking inspiration to Habermas' (1996) notion of ethical discourse and to the deliberative demands of political CSR theory (Scherer \& Palazzo, 2007). They proposed four typologies: instrumental published communication tools as one-way CSR communication (e.g. CSR report or brochure); instrumental unpublished communication for internal use (e.g. codes of conduct or strategic documents); deliberative published communication tools based on open and interactive discourse among multiple actors (e.g. corporate blogs or social media); deliberative unpublished communication also based on open discourse (e.g. meetings for employees, road shows for investors, or stakeholder roundtables).

OECD has recognized the potential of the two-way communication tools (for example, "meetings, hearings or consultation proceedings") to allow "effective stakeholder engagement" (OECD, 2017). In this last perspective, Morsing and Schultz (2006) considered "engagement" as the communication that organizations put out about their "ethical and socially responsible initiatives." (2006). According to Thomson \& Bebbington, "stakeholder engagement describes a range of practices where organizations take a structured approach to consulting with potential stakeholders" (2005).

\subsection{Digital CSR Communication: The Great Potential of Social Media}

Some studies underlined the importance of the Internet and its tools as a facilitator of corporate communicative action on corporate social responsibility issues. It is considered as an additional form of dialogue to integrate newspapers, magazines, meetings, seminars, etc. (Adams \& Frost, 2006; Sikka, 2006; Unerman \& Bennett, 2004).

The advent of the internet not only reorganized the way in which companies collect information, but also redefined stakeholders' expectations (Bonsón \& Ratkai, 2013). In addition, using appropriate internet-based tools, the company can interact with stakeholders at "any moment and with a growing mix of usable tools" (Brondoni, 2006), and can differentiate and customize messages, according to their information needs 
(Adams, \& Frost, 2006; Wheeler, \& Elkington, 2001). In doing this, the company can increase the quantity and the quality of information disclosed without reducing its usability and accessibility (Adams \& Frost, 2006; Herzig \& Godemann, 2010; Moreno \& Capriotti, 2009).

Moreover, internet increases the velocity of the public relations process, facilitating two-way interaction, through its speed of dissemination, access and feedback (Ha \& James, 1998; Sikka, 2006). The use of the company website for disseminating information allows organizations to reach a huge audience at low cost (Jose \& Lee, 2007).

The interest on CSR communication has increased over the last twenty years. Some scholars highlighted the factors (e.g. size, sector, country of origin, financial position) that can influence CSR-related issues on the website (Correa-Garcia et al., 2018; Frostenson et al., 2011; Tagesson et al., 2009; Tetrevova et al., 2019; Wanderley et al., 2008). Others focused on the internet potential to establish a twoway communication and foster a dialogue with stakeholders on CSR topics (Esrock \& Leichty, 1998; Unerman \& Bennett, 2004).

$\square$ Several studies paid attention on the use of the internet for financial reporting (Guillamón-Saorín \& Martínez-López, 2013), sustainability reporting (Hahn \& Kühnen, 2013; Junior et al. 2014; Lodhia, 2014) or integrated reporting (Lodhia \& Stone, 2017). Finally, some authors highlighted that sophisticated Internet-based tools as two-way organization-stakeholder communications were not being harnessed (Guthrie et al., 2008; Herzig \& Godemann, 2010) and, at the same time, a limited use of internet by companies on disseminating CSR topics (Adams \& Frost, 2006; Maier \& Ravazzani, 2018; Moreno \& Capriotti, 2009; Wheeler \& Elkington, 2001).

While at the beginning of the millennium new stakeholders and national legislation introduced by the globalization phenomenon have influenced the business expectations, nowadays, digital and social media are having this impact (Adi et al., 2015). Online social media can be defined as "a group of Internet based applications that build on the ideological and technological foundations of Web 2.0, and that allow the creation and exchange of User Generated Content" (Kaplan \& Haenlein, 2010). It is an umbrella term describing different types of applications, such as collaborative projects (e.g. Wikipedia), blogs/micro-blogs (e.g. Twitter), content communities (e.g. YouTube), social networking sites (e.g. Facebook), virtual game worlds (e.g. World of Warcraft), and virtual social worlds (e.g. Second Life) (Kaplan \& Haenlein, 2009, 2012). Pezet and Casalegno (2017) underlined as the firms, to strength the engagement with society, publish storytelling about their social and environmental concerns on their web sites and official social network pages.

Recent studies pointed out the role of social as vehicles to provide information and to engage with stakeholders. 


\begin{abstract}
$\square$ Manetti and Bellucci argued that "social media and social networks are powerful mechanisms for reaching and keeping in touch with a large number of stakeholders, thus guaranteeing an interactive dialogue with them at very low costs" (2016).
\end{abstract}

Statistics showed that more than a third of the world's population has access to the Internet and out of all the connected users, more than 72 per cent of them are active on social media (Adi et al., 2015; Bullas, 2014).

Platforms like Facebook, Pinterest, Instagram, Tumblr and Twitter have shifted the focus on the users and the social nature of peer communications. Moreover, their continuously growing popularity has led organizations and corporations to adopt the new media to support of marketing communications activities, knowledge transfer, market research, reputation management and customer services/interaction (Stelzner, 2012, Orderofbusiness.net). These channels allow two-way communication between an organization and its audience $(\mathrm{Li} \& \mathrm{Li}, 2014$; Nelson, 2019; Taylor \& Kent, 2014). As showed by Brondoni, "with digital tools and media, corporate communication forges a two-way relationship" (2006).

The participatory nature of social media channels allows companies to distribute information, build relationships, and inform organizational decisions (Rybalko \& Seltzer, 2010). Moreover, these digital channels can contribute to reduce skepticism (Du \& Vieira, 2012). Social media are perceived as more trustworthy than traditional communication channels (Dunn \& Harness. 2018; Sparks \& Bradley, 2018), more effective (Tench \& Jones, 2015) and with greater persuasive power (Zizka, 2017). In addition, social media enjoy greater reach (Kaplan \& Haenlein, 2010) and credibility (Du \& Vieira, 2012). Manetti and Bellucci (2016) assessed if online interaction through social media, particularly Facebook, Twitter, and YouTube, represents an effective stakeholder engagement mechanism in order to define the contents of social, environmental, or sustainability reporting. The authors found that a small number of organizations use social media to engage stakeholders as a means of defining the CSR contents, and that the level of interaction is generally low. Arthur (2011) highlighted as the adoption of digital and social media platforms depends on both the industry sector and nature of the business, as well as on the function digital media plays in the organization's overall strategy.

\title{
3. Methodology
}

The paper aims to contribute to corporate accountability literature by investigating the potential of internet-based communication tools by the DJSI listed-companies to disclose CSR topics. The research focused on Google Directory websites containing observations of DJSI companies to collect the data. Our decision to use internet tools was justified by their potential as direct communication tools able to guarantee transparency. Many studies (among others, Frost et al., 2005; Patten, 2002; Patten and Crampton, 2004; Williams and Pei, 1999) have referenced social disclosures found on companies' web pages. 
The decision to focus the analysis on the DJSI is based on the following reasons. Firstly, this index is the reference for the stock performance of the world's leading companies in terms of economic, environmental and social criteria; this index has increasingly value reliability in CSR activities for investor decisions (Hawn et al., 2018). The DJSI has been recognized as one of the most credible indices to understand trends in different environmental, social and governance ratings (SustainAbility, 2019). Second, since 1999, the DJSI offers coverage in multiple markets (currently, the 317 listed companies are belonging to 24 different industry groups, as shown in the Table 1) and those allows us to investigated differences between sectors. Finally, as recalled above, public information directly accessible through navigation from company websites represents a key point of the revisions of the CSA methodology for assessing DJSI rating.

The list of companies is available on the SAM website; it is updated on Monday, September 24, 2018 and includes the reference to the country and the industry group. Of the 317 listed companies, the $46 \%$ originates from Europe, $27 \%$ from Asia, 22\% from America and the remaining 5\% from Australia. An analysis of the business industry showed that this corporate characteristic is variegate. The main industry groups are capital goods $(10,4 \%)$, banks $(8,5 \%)$, materials $(7,6 \%)$, real estate $(6,5 \%)$, software and services $(5,4 \%)$. The remaining industry groups are represented by companies that cover a percentage up to $5 \%$ of the total (Table 1).

Table 1: DJSI Listed Companies by Industry Groups (Update May 2019)

\begin{tabular}{|l|c|c|}
\hline Industry Group & No. & \% \\
\hline Capital Goods & 33 & $10,40 \%$ \\
\hline Banks & 27 & $8,50 \%$ \\
\hline Materials & 24 & $7,60 \%$ \\
\hline Real Estate & 20 & $6,30 \%$ \\
\hline Software \& Services & 17 & $5,40 \%$ \\
\hline Energy & 16 & $5,00 \%$ \\
\hline Insurance & 16 & $5,00 \%$ \\
\hline Diversified Financials & 15 & $4,70 \%$ \\
\hline Utilities & 15 & $4,70 \%$ \\
\hline Food, Beverage \& Tobacco & 13 & $4,10 \%$ \\
\hline Health Care Equipment \& Services & 12 & $3,80 \%$ \\
\hline Pharmaceuticals, Biotechnology \& Life Sciences & 11 & $3,50 \%$ \\
\hline Technology Hardware \& Equipment & 11 & $3,50 \%$ \\
\hline Transportation & 11 & $3,50 \%$ \\
\hline Automobiles \& Components & 10 & $3,20 \%$ \\
\hline Consumer Durables \& Apparel & 10 & $3,20 \%$ \\
\hline Retailing & 10 & $3,20 \%$ \\
\hline Telecommunication Services & 9 & $2,80 \%$ \\
\hline Commercial \& Professional Services & 7 & $2,20 \%$ \\
\hline Consumer Services & 6 & $1,90 \%$ \\
\hline Food \& Staples Retailing & 6 & $1,90 \%$ \\
\hline Household \& Personal Products & 6 & $1,90 \%$ \\
\hline Media & 6 & $1,90 \%$ \\
\hline Semiconductors \& Semiconductor Equipment & 6 & $1,90 \%$ \\
\hline Total & $\mathbf{3 1 7}$ & $\mathbf{1 0 0 , 0 0 \%}$ \\
\hline
\end{tabular}


The sample is made of 316 companies of the 317 ones in DJSI: one DJSI company has no access to institutional website.

To achieve such goal, a content analysis (Krippendorff, 1980) is used and applied to the corporate web sites of the 316 companies quoted on the DJSI index. Content (or discursive) analysis broadly refers to a systematic approach to extract meaningful information from text documents, including academic papers, corporate reports, company website pages, newspapers, and social media posts. The method of content analysis to investigate different aspects of digital CSR communication is underlined in several studies. For instance, Basil and Erlandson (2008) analyze and compare the websites of a sample of Canadian companies looking at their declared internal and external CSR activities; Bravo, Matute, and Pina (2011) also analyze websites of banks, using content analysis to evaluate the multidimensionality of CSR and its use as a vehicle to reveal corporate identity. Moreover, Chaudhri and Wang's (2007) study of the corporate websites of the top 100 IT Indian companies focuses on the dimensions of prominence of communication, extent of information, and style of presentation websites to communicate CSR (Adi \& Grigore, 2015). Other scholars focused on CSR-related communication and information flow through social media platforms (Chae \& Park, 2018; Lee et al, 2013; McCorkindale, 2010). Based on the previous studies, a coding scheme it was used in the research to identify relevant dimensions to analyze in corporate websites (Table 2).

The indicators are dummy variables representing the presence (assigning the letter " $y$ " so Yes) or absence (letter " $n$ " so No) of each CSR dimensions in corporate websites (Siano et al., 2016); other sub-indicators are numerical variables representing the numbers of clicks need from home page to the CSR dimensions investigated (according to Table 1). We collected data from corporate websites of the companies included in the DJSI. Then, a content analysis was carried out, used as "a research technique for making replicable and valid inferences from data to their context" (Krippendorff, 1980); this step was conducted by three coders, independently and at different times, in order to ensure the reliability of the coding process (Krippendorff, 1980). This method involves the construction of a classification scheme (defining a set of boxes into which to put the data) and developing a set of rules about "what" and "how" to code, measure, and record the data to be classified (Milne and Adler, 1999).

Table 2: Relevant Dimensions Investigated

\begin{tabular}{|l|}
\hline CSR section \\
\hline CSR report \\
\hline General contact (mail/form) \\
\hline CSR specific e-mail /form \\
\hline FAQ about CSR \\
\hline Questionnaire \\
\hline Forum/blog \\
\hline F (facebook); L (linkedin; T(twitter); Y (youtube); I (istagram); Tu (tumblr); G (google+) \\
\hline Report on meetings and consultations \\
\hline Stakeholder engagement dedicated section \\
\hline News section \\
\hline
\end{tabular}


The analysis started from the corporate web site home page; secondly, the stakeholder engagement and corporate social responsibility sections are analyzed (if available). In addition, the proximity to the homepage (click away) are considered to assess the access ease. The "search" facility on each web site is used with the keywords representing the different dimensions (listed on the Table 2). The obtained information is then classified according the model proposed by Seele and Lock (2015). With this basic instruction, each coder went through each document and transcribed each section in which the word was found. To facilitate the recording and to permit the check later, each coder used a coding sheet on Excel. Then, each coder counted the number of the dimensions available and, therefore, how many clicks divide each dimension from the company home page. Following this, a check of the work of each coder was carried out: the three sheets recorded the same sections and the same count.

\section{Results}

This paper investigates instrumental and deliberative published communication tools, according to the Seele and Lock (2015)'s classification, to assess the extent to which DJSI companies are using internet-based tools as stakeholder engagement vehicles and thereby improve their stakeholder dialogue on CRS issues.

Where "not accessible" is indicated, the web page does not work, or no English language is used.

\subsection{Instrumental Published Communication Tools}

The instrumental published communication tools include one-way communication tools, where companies inform stakeholders, and nothing goes back in return. In the current analysis, it includes: CSR section with social, ethical, environmental and economic topics; CSR report, Frequently Asked Questions (FAQs), reports on meetings and/or consultations, news section and accessibility issues.

The table 3 shows the use of the instrumental published communication tools by DJSI listed companies during the period May/June 2019.

A preliminary analysis highlights that almost of all companies include in their web-site a CSR section and a News section to inform stakeholder about their social, environmental, ethic and economic initiatives. At the same time, most of them publish a CSR report. About one third dedicates a specific space to a stakeholder engagement section. Very few companies use the potential of the internet to post report on meetings and consultations with stakeholders and FAQ about CSR contents. Only twelve companies have not the CSR section on their website: the country of the head office appears not be relevant; no prevalence of one country is emerged (within these companies, 3 are in United States; 1 in Australia; 5 in West Europe; 1 in India and 2 in Republic of Korea). The CSR section assume different names: e.g. "sustainability", "corporate social responsibility", "community commitment", and "our responsibility". In the most cases the CSR section is on the home page $(61 \%)$ or one click away from the home page $(25 \%)$. 
The CSR report is an accountability tool published by the $91 \%$ of the DJSI companies. Among these, in the $85 \%$ of the cases (246 listed companies), the report is a sustainability report, written according to Global Reporting Initiative Guidelines; in the $8 \%$ of the cases, the report is the integrated one, writing according to International Integrated Reporting Council Framework. The other companies publish a global annual report containing financial information and a section with non-financial information (about social, environmental and ethic topic).

FAQs are answers to questions which is assumed to have been forwarded by an interested party. Regarding to that, 24 explored web sites use Frequently Asked Questions covering CSR issues as engagement tool. To note that in 2 cases FAQs were placed on the home page, in 12 times one click away, and in 10 cases they were placed two or more clicks away.

The transcripts or reports that disclose speeches, questions and presentations via the Internet can be another engagement tool. Across DJSI companies only 58 regarded this communication tool as important, providing their web site with downloadable documents (presentations, publications and electronic magazines) and locating them not very close to the point of entry (42 companies put the link at these documents, between two to four clicks away).

Accessibility is the ability to provide web sites available to the widest possible audience, regardless of technology or ability, by maximising the usability of the interface. In this regard, only 65 companies showed accessibility statement pages. All of them did it consistently on the home page, even detailing access keys.

Table 3: Instrumental Published Communication Tools Used by DJSI Listed Companies

\begin{tabular}{|l|c|c|c|}
\hline & Yes & No & Not accessible \\
\hline CSR section & 304 & 12 & 1 \\
\hline News section & 300 & 15 & 2 \\
\hline CSR report & 290 & 26 & 1 \\
\hline Stakeholder engagement section & 100 & 215 & 2 \\
\hline Accessibility section & 65 & 250 & 2 \\
\hline Report on meetings and consultations with stakeholders & 58 & 256 & 3 \\
\hline FAQ about CSR & 24 & 291 & 2 \\
\hline
\end{tabular}

\subsection{Deliberative Published Communication Tools}

The deliberative published communication, based on open and interactive discourse among multiple actors, allow two-way communication, like blog/forum and social media. In this category, also e-mail/forms, online questionnaires and surveys are included, because they provide answers by stakeholder even if their interactivity is lower. The on-line communication tools led companies to evolve from a model in which information are supplied in a one-way direction, with local focus and strict monologue, towards a more interactive and participatory approach, "trying to get feedback from a number of stakeholders, or even to engage interested parties" (Isenmann, 2006). 
As shown by data (see Table 4), email or web form as well as social media are adopted by a great part of the DJSI companies, whereas forum/blog and questionnaire are used by a minimum part of business organizations. Despite this, the use of deliberative tools appears lower than the instrumental tools.

Table 4: Deliberative Published Communication Tools Used by DJSI Listed Companies

\begin{tabular}{|l|c|c|c|}
\hline & Yes & No & Not accessible \\
\hline General contacts (mail/form) & 263 & 51 & 3 \\
\hline (with also CSR Specific e-mail /form) & 108 & 206 & 3 \\
\hline Social media & 261 & 55 & 1 \\
\hline Forum/Blog & 35 & 280 & 2 \\
\hline Questionnaire with CSR contents & 5 & 310 & 2 \\
\hline
\end{tabular}

E-mails or, alternatively, web forms are the most used tools. Web forms allow stakeholders to submit data writing their message straight on the page. Almost all organisations have an e-mail address or a web form to meet general enquiries. The analysis underlines that 122 of web sites adopted e-mail as common communication medium, whereas 113 used web forms, and 28 chose both (the remaining opts for physical address and/or telephone number). Among these, 108 companies devoted e-mails or web forms to specific CSR purposes. Most web sites link to e-mail addresses and web forms are on the home page or one click away (87,5\% of the 263). The number of clicks required to access CSR contacts is normally greater than those required to arrive at the generic e-mails or forms: about half of them are two or more click away. Forums and blogs are dialogue mechanisms for holding discussions that have a great communicative potential (Unerman \& Bennett, 2004). Only 35 companies implemented them. Among who did, in 26 cases blogs were placed on the home page or one click away. It was found that feedback questionnaires are used by only 1, 5\% of the DJSI companies (available far from the home page, two or more clicks away). The analysis of the 316 websites shows that social media are diffused internet-based tools: about twothird of the sample, in fact, presents link to one social channel and 71 of them have, at least, links to Facebook, LinkedIn, Twitter, YouTube and Instagram (Table 5).

Table 5: Social Channels Used by DJSI Listed Companies

\begin{tabular}{|l|c|c|}
\hline & Yes & No \\
\hline Facebook & 213 & 48 \\
\hline LinkedIn & 222 & 39 \\
\hline Twitter & 229 & 32 \\
\hline YouTube & 180 & 81 \\
\hline Instagram & 104 & 157 \\
\hline Tumblr & 5 & 256 \\
\hline Google+ & 29 & 232 \\
\hline RSS & 47 & 214 \\
\hline Pinterest & 19 & 242 \\
\hline
\end{tabular}


Regarding these five social channels (Facebook, LinkedIn, Twitter, YouTube, Instagram), US, UK, Japan and France are the country where are located the DJSI companies that more of the others used the social media (Table 6).

Table 6: Companies' Country of Origin Where Social Channels Are Most Used

\begin{tabular}{|l|l|}
\hline Country of origin & Use of Social media \\
\hline United States & $20 \%$ \\
\hline United Kingdom & $9 \%$ \\
\hline Japan & $8 \%$ \\
\hline France & $8 \%$ \\
\hline
\end{tabular}

Another interesting consideration emerges analysing the sectors in which the companies are operating (Table 7).

Table 7: Sectors of Companies that Use Most Social Media

\begin{tabular}{|l|c|}
\hline Industry Group & Social media (yes) \\
\hline Materials & 21 \\
\hline Capital Goods & 20 \\
\hline Banks & 17 \\
\hline Insurance & 14 \\
\hline Software \& Services & 14 \\
\hline Utilities & 13 \\
\hline Real Estate & 12 \\
\hline Energy & 12 \\
\hline Health Care Equipment \& Services & 11 \\
\hline Diversified Financials & 10 \\
\hline Pharmaceuticals, Biotechnology \& Life Sciences & 10 \\
\hline Automobiles \& Components & 9 \\
\hline Transportation & 9 \\
\hline Food, Beverage \& Tobacco & 8 \\
\hline Media & 5 \\
\hline Retailing & 5 \\
\hline Technology Hardware \& Equipment & 5 \\
\hline Commercial \& Professional Services & 5 \\
\hline Consumer Durables \& Apparel & 5 \\
\hline Food \& Staples Retailing & 5 \\
\hline Household \& Personal Products & 5 \\
\hline Telecommunication Services & 4 \\
\hline Consumer Services & 4 \\
\hline Semiconductors \& Semiconductor Equipment & 2 \\
\hline Total & $\mathbf{2 2 5}$ \\
\hline
\end{tabular}

The analysis shows that among the companies that use social media, the $t$ first two positions are covered by businesses operating in materials and capital goods sectors, whereas the following ones refer to service sector. 


\section{Discussion and Conclusion}

The study investigates the extent to which the DJSI listed companies are using the internet-based tools to foster CSR communication. Internet-based technologies represents timely communication that organisations can harness to facilitate and to enrich stakeholder understanding about CSR initiatives, and to personalise information to match different stakeholders' needs (Lodhia et al., 2017; Kim, 2019; Moratis and Brandt, 2017; Nelson, 2019; Unerman \& Bennett, 2004). Internet allows companies to provide updated information that remain permanently available on the web and the internet users can decide what and when to view the subjects they choose (Wanderley, et al. 2008).

The study reveals the predominant use of the one-way communication tools from the organization to its stakeholders. In fact, even if e-mail/web form could allow bidirectional exchange of information between company and its stakeholders, the interaction in this case is on a one-to-one basis and the participatory nature required to internet to foster open and interactive discourse is not guaranteed.

$\square$ As pointed out by Grunig \& Hunt (1984), one-way communication is viewed as 'telling, not listening' with the purpose to inform the public not necessary with a persuasive intent. Under this perspective, the analysis shows that the nonfinancial report is one of the most used communication tools to inform public about corporate initiatives. The results underline that in the $91 \%$ of analyzed companies the report is specifically related to sustainability practices (included what it is disclosed on integrated reports, non-financial declaration attached to annual reports). Some studies showed that companies used Internet for sustainability disclosure in the same way as other reporting media, without benefit from the advantages created by the on-line tools (Del Bosco, 2017).

In addition, the findings of the paper reveal that most companies seem to be reluctant to exploit forum or blogs but a great part of them use social channels to stimulate sharing information and, engaging stakeholders. In the most of cases, the links to corporate social media are on the home page allowing faster and easier access.

This result can represent a positive aspect, regarding the diffusion of social channels, but a not good point if the attention is on the two-way communication tools as forum and blogs. As pointed out by Lodhia et al. (2017), in fact "internetfacilitated communications with multiple stakeholder audiences and increased stakeholder engagement on social media opens organisations to increased public scrutiny and attack from disgruntled stakeholders who are practiced at using social networking sites to communicate their grievances about corporations' practices and policies". The lack of tools as forum or blogs can represent, in fact, a loss of opportunity to engage effectively with stakeholders and, so, to obtain feedback and evaluation about CSR behaviours. 
Despite this, it is relevant to note that the social networks tool responds to the need to reach a wide audience and to influence user perceptions about the merit of the firm's CSR (Adi et al., 2015). Social media can be considered a tool of two-way communication that allows companies to have a dialogue with stakeholders: these tools allow to satisfy stakeholder concurrent expectations but also, they have the potential influence on those expectations, as well as letting those expectations influence and change the company itself. As stated by Dunn \& Harness (2018), social media are an important tool to communicate CSR for their most powerfully affects values-driven attributions.

In contrast with the findings suggested by several studies according to which country specific institutional framework, legal origin and enforcement and national business systems affects firms' operation and behaviours (Bansal \& Knox-Hayes, 2013; Jackson \& Apostolakou, 2010; Wanderley et al., 2008;), the space is not relevant in the present study. As showed by Adelopo et al. (2012), the web accessibility of CSR communication is not significantly influenced by country of origin. The analysis of country of origin, in fact, has shown no prevalence of a country to another one in the typologies and frequency of internet-based tools, except to social media, that are more developed in United States, Japan and France.

The influence of companies' sector seems to be marginally relevant. The social media are prevalent used to communicate CSR by companies operating in services sector. However, the first two position are covered by companies operating in materials and capitals goods sectors, confirming the correlation between the high impact sectors (sectors that generate negative externalities) and the need to do more to retain, maintain or obtain the acceptance of stakeholders because of the perceived higher societal expectation on them (Adelopo et al., 2012).

Another aspect emerged from the analysis concern the language. All companies have web sites published in English and in the mother tongue language spoken in the head office: in running the communication process companies takes for granted that anyone is formally literate in those languages; no evidence of the availability of translators, interpreters, or multilingual facilitators is presented in the different websites.

Further interesting considerations emerged from the results are related to accessibility, in terms of the opportunity given to impaired individuals to benefit of web content. A considerable portion of DJSI web sites (79\%) did not provide accessibility information, seemingly disregarding the opportunity for stakeholder with disabilities to engage with them. This critical evidence represents a contradiction that can cause scepticism and some credibility issues. In fact, it is difficult to succeed in the stakeholders' engagement communicating the corporate social commitment if communication tools adopted by the company do not allow everyone to access information. Therefore, the accessibility is one of the themes that the management should take into consideration in defining the CSR communication strategy. Corporate social responsibility communication can have negative consequences if stakeholders become suspicious and perceive predominantly extrinsic motives in companies' social initiatives (Du et al., 2010).

This research stands in support of the existing literature that indicates various online communication techniques can be used to deepen online relationships (Lovejoy et al. 2012; Rybalko \& Seltzer 2010). Moreover, the research aims to 
contribute to the literature on CSR communication underlining that companies, for which sustainability has a predominant role in the mission and vision, still use more one-way communication tools and investigating the elements that can influence the adoption of the on-line communication tools. In addition, all studies highlighted a growing number of communication tools internet-based, both one-way and twoway, but no one covers all possible internet-based tools, available on the company website. Finally, little attention was given to the communication tools of the DJSI companies in the last years, above all considering the growing importance of "public information" recognized by the SAM.

The paper presents also practical implication for practitioners and company managers: it is imperative for managers to have a deeper understanding of critical issues related to the use of digital tools for the CSR communication to create stakeholder engagement and to manage stakeholder attributions towards CSR activities of companies. The reputation of the company is also another element that managers must consider in the definition of CSR communication strategies and the choice of the most effective tools. In particular, the use of internet and social media can proactively engage stakeholders and have a positive effect on their scepticism. Relevant information that can help in perceiving the CSR efforts more genuine and authentic should underline the process behind the CSR activities implementations and the companies' genuine involvement to the cause (Dunn and Harness, 2018).

This study presents three main limitations. First, many of the descriptive findings are likely to be time-bound, because both technology and corporate use of the web continue to evolve. Further research addressing the evolving engagement initiative taking place through the web would be welcomed. Second, the study does not investigate websites set up in languages different from English. Third, even if a considerable caution was used during the research process in the DJSI websites, the content analysis approach could present one main limit. The keywords used to track the information, or the general overview of the different web pages cannot capture enough the overall information available (as noted also by the study of Paisey \& Paisey, 2006).

The paper investigates the potential of internet-based communication tools to disclose CSR topics analysing the perspective of DJSI listed companies.

For a deeper understanding of the phenomenon, it should be interesting to develop future research based on stakeholder perspective to investigate their perceptions towards CSR communication activities. Finally, a comprehension of stakeholder expectation and needs related to CSR communication could be investigated.

\section{Bibliography}

Abeza, G., O’Reilly, N., Finch, D., Séguin, B., \& Nadeau, J. (2018). The Role of Social Media in the Co-Creation of Value in Relationship Marketing: A Multi-Domain Study. Journal of Strategic Marketing, 1-22.

http://dx.doi.org/10.1080/0965254X.2018.1540496.

Adams, C. A., \& Frost, G. R. (2006). The Internet and Change in Corporate Stakeholder Engagement and Communication Strategies on Social and Environmental Performance. Journal of Accounting \& Organizational Change, 2(3), 281-303. 
http://dx.doi.org/10.1108/18325910610690090

Adams, C.A., \& Frost, G.R. (2006). Accessibility and Functionality of the Corporate Web Site: Implications for Sustainability Reporting. Business Strategy and the Environment, 15, 275-287. http://dx.doi.org/10.1002/bse.531

Adams, C. A., \& Larrinaga-González, C. (2007). Engaging with Organisations in Pursuit of Improved Sustainability Accounting and Performance. Accounting, Auditing \& Accountability Journal, 20(3), 333-355. http://dx.doi.org/10.1108/09513570710748535

Adams, C. A., Hill, W. Y., \& Roberts, C. B. (1998). Corporate Social Reporting Practices in Western Europe: Legitimating Corporate Behaviour? The British Accounting Review, 30(1), 1-21. http://dx.doi.org/10.1006/bare.1997.0060

Adelopo, I., Cea Moure, R., Vargas Preciado, L., \& Obalola, M. (2012). Determinants of WebAccessibility of Corporate Social Responsibility Communications. Journal of Global Responsibility, 3(2), 235-247. http://dx.doi.org/10.1108/20412561211260539

Adi, A., \& Grigore, G. (2015). Communicating CSR on Social Media: The Case of Pfizer's Social Media Communications in Europe. In Corporate Social Responsibility in the Digital Age (pp. 143163). Emerald Group Publishing Limited.

Adi, A., Crowther, D., \& Grigore, G. (Eds.) (2015). Introduction to Corporate Social Responsibility in the Digital Age. In Corporate Social Responsibility in the Digital Age (pp. ix-xvi). Emerald Group Publishing Limited.

Andriof, J., \& Waddock, S. (2002). Unfolding Stakeholder Thinking I and II. Greenleaf-Publishing Limited.

Arthur, L. (2011). Are Corporations Giving up on Social Media? Retrieved from http://www.forbes.com/sites/lisaarthur/2011/11/01/are-corporations-giving-up-on-social-media/

Backstrand, K., \& Saward, M. (2004). Democratizing Global Governance: Stakeholder Democracy at the World Summit for Sustainable Development. In American Political Science Association Conference, Chicago.

Bansal, P., \& Knox-Hayes, J. (2013). The Time and Space of Materiality in Organizations and the Natural Environment. Organization \& Environment, 26(1), 61-82.

http://dx.doi.org/10.1177/1086026612475069

Bartkus, B., Glassman, M., \& McAfee, B. (2002). Do Large European, US and Japanese Firms Use their Web Sites to Communicate their Mission? European Management Journal, 20(4), 423-429. http://dx.doi.org/10.1016/S0263-2373(02)00065-8

Basil, D. Z., \& Erlandson, J. (2008). Corporate Social Responsibility Website Representations: a Longitudinal Study of Internal and External Self-Presentations. Journal of Marketing Communications, 14(2), 125-137. http://dx.doi.org/10.1080/13527260701858497

Bebbington, J. (1997). Engagement, Education and Sustainability: A Review Essay on Environmental Accounting. Accounting, Auditing \& Accountability Journal, 10(3), 365-381. http://dx.doi.org/10.1108/09513579710178115

Bebbington, J., Brown, J., Frame, B., \& Thomson, I. (2007). Theorizing Engagement: The Potential of a Critical Dialogic Approach. Accounting, Auditing \& Accountability Journal, 20(3), 356-381. http://dx.doi.org/10.1108/09513570710748544

Bhattacharya, C. B., \& Sen, S. (2004). Doing Better at Doing Good: When, Why, and How Consumers Respond to Corporate Social initiatives. California Management Review, 47(1), 9-24. http://dx.doi.org/10.2307/41166284

Blackburn, N., Hooper, V., Abratt, R., \& Brown, J. (2018). Stakeholder Engagement in Corporate Reporting: Towards Building a Strong Reputation. Marketing Intelligence \& Planning, 36(4), 484-497. 
http://dx.doi.org/10.1108/MIP-10-2017-0236

Bochenek, L. M., \& Blili, S. (2014). Social Media Champions-Drivers and Sophistication Process of Social Media Strategic Management. In Social Media in Strategic Management (pp. 143-167). Emerald Group Publishing Limited.

Bondy, K., Matten, D., \& Moon, J. (2004). The Adoption of Voluntary Codes of Conduct in MNCs: A Three-Country Comparative Study. Business and Society Review, 109(4), 449-477.

http://dx.doi.org/10.1111/j.0045-3609.2004.00205.x

Bonsón, E., \& Ratkai, M. (2013). A Set of Metrics to Assess Stakeholder Engagement and Social Legitimacy on a Corporate Facebook Page. Online Information Review, 37(5), 787-803.

http://dx.doi.org/10.1108/OIR-03-2012-0054

Bosetti, L. (2018). Web-Based Integrated CSR Reporting: An Empirical Analysis. Symphonya. Emerging Issues in Management (symphonya.unimib.it), (1), 18-38.

http://dx.doi.org/10.4468/2018.1.02bosetti

Bravo, R., Matute, J., \& Pina, J. M. (2012). Corporate Social Responsibility as a Vehicle to Reveal the Corporate Identity: A study Focused on the Websites of Spanish Financial Entities. Journal of Business Ethics, 107(2), 129-146.

http://dx.doi.org/10.1007/s10551-011-1027-2

Brondoni, S. (2006). Ouverture de 'Corporate Governance Communication'. Symphonya. Emerging Issues in Management (symphonya.unimib.it), (1), 1-7.

http://dx.doi.org/10.4468/2006.2.01ouverture

Brondoni, S. (2006). Corporate Communication and Global Markets. Symphonya. Emerging Issues in Management (symphonya.unimib.it), (2), 9-37.

http://dx.doi.org/10.4468/2006.2.01ouverture

Bullas, J. (2014). 22 Social Media Facts and Statistics You Should Know in 2014. Retrieved from http://www.jeffbullas.com/2014/01/17/20-social-media-facts-and-statistics-you-shouldknow-in2014/\#еjIu8FiK4kGyMQiZ.99.

Chae, B., \& Park, E. (2018). Corporate Social Responsibility (CSR): A Survey of Topics and Trends Using Twitter Data and Topic Modeling. Sustainability, 10(7), 2231.

http://dx.doi.org/10.3390/su10072231

Chaudhri, V., \& Wang, J. (2007). Communicating Corporate Social Responsibility on the Internet: A Case Study of the Top 100 Information Technology Companies in India. Management Communication Quarterly, 21(2), 232-247.

http://dx.doi.org/10.1177/0893318907308746

Cho, C., Michelon, G., Patten, D., \& Roberts, R. (2015). CSR Disclosure: the More Things Change...? Accounting, Auditing and Accountability Journal, 28(1), 14-35.

http://dx.doi.org/10.1108/AAAJ-12-2013-1549

Correa-Garcia, J. A., Garcia-Benau, M. A., \& Garcia-Meca, E. (2018). CSR Communication Strategies of Colombian Business Groups: An Analysis of Corporate Reports. Sustainability, 10(5), 1602.

http://dx.doi.org/10.3390/su10051602

Del Bosco, B. (2017). The Evolution of CSR Communication on the Internet. Impresa ProgettoElectronic Journal of Management, (1), 1-29, https://www.impresaprogetto.it/essays/2017-1/del$\underline{\text { bosco }}$

Du, S., \& Vieira, E. T. (2012). Striving for Legitimacy Through Corporate Social Responsibility: Insights from Oil Companies. Journal of Business Ethics, 110(4), 413-427.

http://dx.doi.org/10.1007/s10551-012-1490-4

Du, S., Bhattacharya, C. B., \& Sen, S. (2010). Maximizing Business Returns to Corporate Social Responsibility (CSR): The Role of CSR Communication. International Journal of Management Reviews, 12(1), 8-19. 
http://dx.doi.org/10.1111/j.1468-2370.2009.00276.x

Dunn, K., \& Harness, D. (2018). Communicating Corporate Social Responsibility in a Social World: The Effects of Company-Generated and User-Generated Social Media Content on CSR Attributions and Scepticism. Journal of Marketing Management, 34(17-18), 1503-1529. http://dx.doi.org/10.1080/0267257X.2018.1536675

Esrock, S.L., \& Leichty, G.B. (1998). Social Responsibility and Corporate Web Pages: SelfPresentation or Agenda Setting? Public Relations Review, 24(3), 305-319.

http://dx.doi.org/10.1016/S0363-8111(99)80142-8

Frostenson, M., Helin, S., \& Sandström, J. (2011). Organising Corporate Responsibility Communication through Filtration: A Study of Web Communication Patterns in Swedish Retail. Journal of Business Ethics, 100(1), 31-43.

http://dx.doi.org/10.1007/s10551-011-0771-7

Grunig, J. E., \& Hunt, T. T. (1984). Managing Public Relations CL. J. E. Grunig, \& T. Hunt, Managing Public Relations CL. Cengage Learning.

Guillamón-Saorín, E., \& Martínez-López, F. J. (2013). Corporate Financial Communication and the Internet: Manipulating Investor Audiences?. Online Information Review, 37(4), 518-537.

http://dx.doi.org/10.1108/OIR-10-2011-0142

Guthrie, J. \& Parker, L. D. (1990). Corporate Social Disclosure Practices: A Comparative International Analysis. Advances in Public Interest Accounting, 3, 159-175. Emerald, ISSN 10417060, ZDB-ID 901002-6

Guthrie, J., Cuganesan, S., \& Ward, L. (2008). Disclosure Media for Social and Environmental Matters within the Australian Food and Beverage Industry. Social and Environmental Accountability Journal, 28(1), 33-44.

http://dx.doi.org/10.1080/0969160X.2008.9651789

Ha, L., \& James, E. L. (1998). Interactivity Reexamined: A Baseline Analysis of Early Business Web Sites. Journal of Broadcasting \& Electronic Media, 42(4), 457-474.

http://dx.doi.org/10.1080/08838159809364462

Habermas, J. (1990). Moral Consciousness and Communicative action. MIT press.

Hahn, R., \& Kühnen, M. (2013). Determinants of Sustainability Reporting: A Review of Results, Trends, Theory, and Opportunities in an Expanding Field of Research. Journal of Cleaner Production, 59, 5-21.

http://dx.doi.org/10.1016/j.jclepro.2013.07.005

Hawn, O., Chatterji, A. K., \& Mitchell, W. (2018). Do Investors Actually Value Sustainability? New Evidence from Investor Reactions to the Dow Jones Sustainability Index (DJSI). Strategic Management Journal, 39(4), 949-976.

http://dx.doi.org/10.1002/smj.2752

Herzig, C., \& Godemann, J. (2010). Internet-Supported Sustainability Reporting: Developments in Germany. Management Research Review, 33(11), 1064-1082.

http://dx.doi.org/10.1108/01409171011085903

Jackson, G., \& Apostolakou, A. (2010). Corporate Social Responsibility in Western Europe: An Institutional Mirror or Substitute? Journal of Business Ethics, 94(3), 371-394.

https://doi:10.1007/s10551-009-0269-8

Jose, A., \& Lee, S. (2007). Environmental Reporting of Global Corporations: A Content Analysis Based on Website Disclosures. Journal of Business Ethics, 72(4,) 307-321.

http://dx.doi.org/10.1007/s10551-006-9172-8

Junior, R. M., Best, P. J., \& Cotter, J. (2014). Sustainability Reporting and Assurance: A Historical Analysis on a World-Wide Phenomenon. Journal of Business Ethics, 120(1), 1-11.

http://dx.doi.org/10.1007/s10551-013-1637-y 
Kaplan, A. M. \& Haenlein, M. (2009), Consumers, Companies, and Virtual Social Worlds: a Qualitative Analysis of Second Life, Advances in Consumer Research, Vol. 36 No. 1, pp. 873874.

Kaplan, A. M., \& Haenlein, M. (2010). Users of the World, Unite! The Challenges and Opportunities of Social Media. Business Horizons, 53(1), 59-68.

http://dx.doi.org/10.1016/j.bushor.2009.09.003

Kaplan, A.M. \& Haenlein, M. (2012). Social Media: Back to the Roots and Back to the Future. Journal of Systems and Information Technology, 14(2), 101-104.

http://dx.doi.org/10.1108/13287261211232126

Kim, Y. (2014). Strategic Communication of Corporate Social Responsibility (CSR): Effects of Stated Motives and Corporate Reputation on Stakeholder Responses. Public Relations Review, 40(5), 838-840.

http://dx.doi.org/10.1016/j.pubrev.2014.07.005

Kim, S., \& Ferguson, M. A. T. (2018). Dimensions of Effective CSR Communication Based on Public Expectations. Journal of Marketing Communications, 24(6), 549-567.

http://dx.doi.org/10.1080/13527266.2015.1118143

Kim, S. (2019). The Process Model of Corporate Social Responsibility (CSR) Communication: CSR Communication and its Relationship with Consumers' CSR Knowledge, Trust, and Corporate Reputation Perception. Journal of Business Ethics, 154(4), 1143-1159.

http://dx.doi.org/10.1007/s10551-017-3433-6

Krippendorff, K. (2018). Content Analysis: An Introduction to its Methodology. Sage Publications.

Herzig, C., \& Godemann, J. (2010). Internet-Supported Sustainability Reporting: Developments in Germany. Management Research Review, 33(11), 1064-1082.

http://dx.doi.org/10.1108/01409171011085903

Isenmann, R. (2006). CSR Online: Internet Based Communication, in Management Models for Corporate Social Responsibility. Springer, Berlin, Heidelberg.

http://dx.doi.org/10.1007/3-540-33247-2_30

ISO-OECD, Practical Overview of the Linkages Between ISO 26000:2010, Guidance on Social Responsibility, and OECD Guidelines for Multinational Enterprises (Version: 7 February 2017)

Lee, K., Oh, W. Y., \& Kim, N. (2013). Social Media for Socially Responsible Firms: Analysis of Fortune 500's Twitter Profiles and their CSR/CSIR Ratings. Journal of Business Ethics, 118(4), 791-806.

http://dx.doi.org/10.1007/s10551-013-1961-2

Li, Z., \& Li, C. (2014). Tweet or "re-tweet"? An Experiment of Message Strategy and Interactivity on Twitter. Internet Research, 24(5), 648-667.

http://dx.doi.org/10.1108/IntR-11-2013-0233

Lim, J. S., \& Greenwood, C. A. (2017). Communicating Corporate Social Responsibility (CSR): Stakeholder Responsiveness and Engagement Strategy to Achieve CSR Goals. Public Relations Review, 43(4), 768-776.

http://dx.doi.org/10.1016/j.pubrev.2017.06.007

Lodhia, S. (2014). Factors Influencing the Use of the World Wide Web for Sustainability Communication: An Australian Mining Perspective. Journal of Cleaner Production, 84, 142-154. http://dx.doi.org/10.1016/j.jclepro.2014.08.085

Lodhia, S., \& Stone, G. (2017). Integrated Reporting in an Internet and Social Media Communication Environment: Conceptual Insights. Australian Accounting Review, 27(1), 17-33. http://dx.doi.org/10.1111/auar.12143

Lovejoy, K., Waters, R. D., \& Saxton, G. D. (2012). Engaging Stakeholders Through Twitter: How Nonprofit Organizations are Getting More Out of 140 Characters or Less. Public Relations Review, 38(2), 313-318.

http://dx.doi.org/10.1016/j.pubrev.2012.01.005

Edited by: Niccolò Cusano University

ISSN: 1593-0319 
Maier, C. D., \& Ravazzani, S. (2019). Bridging Diversity Management and CSR in Online External Communication. Corporate Communications: An International Journal,24(2), 269-286. http://dx.doi.org/10.1108/CCIJ-01-2018-0015

Manetti, G., \& Bellucci, M. (2016). The Use of Social Media for Engaging Stakeholders in Sustainability Reporting. Accounting, Auditing \& Accountability Journal, 29(6), 985-1011.

http://dx.doi.org/10.1108/AAAJ-08-2014-1797

McCorkindale, T. (2010). Can You See the Writing on My Wall? A Content Analysis of the Fortune 50's Facebook Social Networking Sites. Public Relations Journal, 4, 1-13. Available at https://prjournal.instituteforpr.org/wp-content/uploads/2010McCorkindale.pdf

Mohr, J., \& Spekman, R. (1994). Characteristics of Partnership Success: Partnership Attributes, Communication Behavior, and Conflict Resolution Techniques. Strategic Management Journal, 15(2), pp. 135-152.

http://dx.doi.org/10.1002/smj.4250150205

Moreno, A., \& Capriotti, P. (2009). Communicating CSR, Citizenship and Sustainability on the Web. Journal of Communication Management, 13(2), 157-175 http://dx.doi.org/10.1108/13632540910951768

Moratis, L., \& Brandt, S. (2017). Corporate Stakeholder Responsiveness? Exploring the State and Quality of GRI-Based Stakeholder Engagement Disclosures of European Firms. Corporate Social Responsibility and Environmental Management, 24(4), 312-325.

http://dx.doi.org/10.1002/csr.1408

Morsing, M., \& Schultz, M. (2006). Corporate Social Responsibility Communication: Stakeholder Information, Response and Involvement Strategies. Business Ethics: A European Review, 15(4), 323-338.

http://dx.doi.org/10.1111/j.1467-8608.2006.00460.x

Mosca, F., \& Civera, C. (2017). The Evolution of CSR: An Integrated Approach. Symphonya. Emerging Issues in Management, (symphonya.unimib.it), (1), 16-35. http://dx.doi.org/10.4468/2017.1.03mosca.civera

Nelson, E. K. (2019). Come on Feel the Noise: The Relationship Between Stakeholder Engagement and Viral Messaging Through an Association's Twitter Use. International Review on Public and Nonprofit Marketing, 1-19.

http://dx.doi.org/10.1007/s12208-019-00219-1

Owen, D. L., Swift, T., \& Hunt, K. (2001, January). Questioning the Role of Stakeholder Engagement in Social and Ethical Accounting, Auditing and Reporting. Accounting Forum, 25(3), 264-282.

http://dx.doi.org/10.1111/1467-6303.00066

Parsa, S., \& Kouhy, R. (2008). Social Reporting by Companies Listed on the Alternative Investment Market. Journal of Business Ethics, 79(3), 345-360.

http://dx.doi.org/10.1007/s10551-007-9402-8

Paisey, C., \& Paisey, N. J. (2006). And They All Lived Happily Ever After? Exploring the Possibilities of Mobilising the Internet to Promote a More Enabling Accounting for Occupational Pension Schemes. Accounting, Auditing \& Accountability Journal, 19(5), 719-758.

http://dx.doi.org/10.1108/09513570610689677

Pezet, E., \& Casalegno, C. (2017). Balancing Under and Over Communication in Sustainability. Symphonya. Emerging Issues in Management, (symphonya.unimib.it), (1), 95-110. http://dx.doi.org/10.4468/2017.1.08pezet.casalegno

Re, P., \& Giachino, C. (2018). CSR in Small and Medium Companies and Stakeholder's Relationships. Symphonya. Emerging Issues in Management, (symphonya.unimib.it), (1), 76-90. http://dx.doi.org/10.4468/2018.1.06re.giachino

Rybalko, S., \& Seltzer, T. (2010). Dialogic Communication in 140 Characters or Less: How Fortune 500 Companies Engage Stakeholders Using Twitter. Public Relations Review, 36(4), 336-341. 
(C) SYMPHONYA Emerging Issues in Management, 2, 2019

symphonya.unicusano.it

http://dx.doi.org/10.1016/j.pubrev.2010.08.004

Siano, A., Conte, F., Amabile, S., Vollero, A., Piciocchi, P. (2016). Communicating Sustainability: An Operational Model for Evaluating Corporate Websites. Sustainability, 8(9): 950. http://dx.doi.org/10.3390/su8090950

Schaltegger, S., \& Burritt, R. (2018). Business Cases and Corporate Engagement with Sustainability: Differentiating Ethical Motivations. Journal of Business Ethics, 147(2), 241-259. http://dx.doi.org/10.1007/s10551-015-2938-0

Scherer, A. G., \& Palazzo, G. (2007). Toward a Political Conception of Corporate Responsibility: Business and Society Seen from a Habermasian Perspective. Academy of Management Review, 32(4), 1096-1120. http://dx.doi.org/10.5465/amr.2007.26585837

Seele, P., \& Lock, I. (2015). Instrumental and/or Deliberative? A Typology of CSR Communication Tools. Journal of Business Ethics, 131(2), 401-414. http://dx.doi.org/10.1007/s10551-014-2282-9

Sikka, P. (2006). The Internet and Possibilities for Counter Accounts: Some Reflections. Accounting, Auditing \& Accountability Journal, 19(5), 759-769. http://dx.doi.org/10.1108/09513570610689686

Sparks, B. A., \& Bradley, G. L. (2018). A "Triple A" Typology of Responding to Negative Consumer Generated Online Reviews. Journal of Hospitality and Tourism Research, 41(6), 719745.

http://doi.org/10.1177/1096348014538052

Swift, T. (2001). Trust, Reputation and Corporate Accountability to Stakeholders. Business Ethics: A European Review, 10(1), 16-26.

http://dx.doi.org/10.1111/1467-8608.00208

Stelzner, M. A. (2012). 2012 Social Media Marketing Industry Report: How Marketers Are Using Social Media to Grow their Businesses. Social Media Examiner.

SustainAbility (2019), Rate the Raters 2019: Expert Views on ESG Ratings February 2019, available at www.sustainability.com.

Tagesson, T., Blank, V., Broberg, P., \& Collin, S. (2009). What Explains the Extent and Content of Social and Environmental Disclosures on Corporate Websites: A Study of Social and Environmental Reporting in Swedish Listed Corporations. Corporate Social Responsibility and Environmental Management, 16(6), 352-364. http://dx.doi.org/10.1002/csr.194

Taylor, M., \& Kent, M. L. (2014). Dialogic Engagement: Clarifying Foundational Concepts. Journal of Public Relations Research, 26(5), 384-398. http://dx.doi.org/10.1080/1062726X.2014.956106

Tench, R., \& Jones, B. (2015). Social Media: The Wild West of CSR Communications. Social Responsibility Journal, 11(2), 290-305.

http://dx.doi.org/10.1108/SRJ-12-2012-0157

Tetrevova, L., Patak, M., \& Kyrylenko, I. (2019). Web-Based CSR Communication in PostCommunist Countries. Applied Economics Letters, 26(10), 866-871.

http://dx.doi.org/10.1080/13504851.2018.1508866

Thomson, I., \& Bebbington, J. (2005). Social and Environmental Reporting in the UK: a Pedagogic Evaluation. Critical Perspectives on Accounting, 16(5), 507-533.

http://dx.doi.org/10.1016/j.cpa.2003.06.003

Unerman, J., \& Bennett, M. (2004). Increased Stakeholder Dialogue and the Internet: Towards Greater Corporate Accountability or Reinforcing Capitalist Hegemony?. Accounting, Organizations and Society, 29(7), 685-707.

http://dx.doi.org/10.1016/j.aos.2003.10.009 
(C) SYMPHONYA Emerging Issues in Management, 2, 2019

symphonya.unicusano.it

United Nations (2011). Guiding Principles on Business and Human Rights Implementing the United Nations, https://www.ohchr.org/documents/publications/guidingprinciplesbusinesshr_en.pdf

Yekini, K. C., Omoteso, K., \& Adegbite, E. (2019). CSR Communication Research: A Theoreticalcum-Methodological Perspective from Semiotics. Business \& Society.

http://dx.doi.org/10.1177/0007650319843623

Wanderley, L. S. O., Lucian, R., Farache, F., \& de Sousa Filho, J. M. (2008). CSR Information Disclosure on the Web: A Context-Based Approach Analysing the Influence of Country of Origin and Industry Sector. Journal of Business Ethics, 82(2), 369-378.

http://dx.doi.org/10.1007/s10551-008-9892-z

Wheeler, D., \& Elkington, J. (2001). The End of the Corporate Environmental Report? Or the Advent of Cybernetic Sustainability Reporting and Communication. Business Strategy and the Environment, 10(1), 1-14.

http://dx.doi.org/10.1002/1099-0836(200101/02)10:1<1::AID-BSE274>3.0.CO;2-0

Williams, S. M., \& Ho Wern Pei, C. A. (1999). Corporate Social Disclosures by Listed Companies on their Web Sites: An International Comparison. The International Journal of Accounting, 34(3), 389-419.

http://dx.doi.org/10.1016/S0020-7063(99)00016-3

Zizka, L. (2017). The (Mis) Use of Social Media to Communicate CSR in Hospitality: Increasing Stakeholders'(Dis) Engagement through Social Media. Journal of Hospitality and Tourism Technology, 8(1), 73-86.

http://dx.doi.org/10.1108/JHTT-07-2016-0037 